\title{
FOREST-BASED INDUSTRY IN PARANÁ: BIOENERGY CLUSTERING AND GENERATION
}

\author{
Amarildo Hersen ${ }^{1 *}$, Romano Timofeiczyk Junior ${ }^{2}$, Dimas Agostinho da Silva ${ }^{3}$, João Carlos Garzel Leodoro da \\ Silva ${ }^{4}$, Jandir Ferrera de Lima ${ }^{5}$ \\ ${ }^{1 *}$ Federal University of Paraná, Post-graduate Program in Forest Engineering, Curitiba, Paraná, Brazil - email: \\ amarildohersen@yahoo.com.br \\ ${ }^{2}$ Federal University of Paraná, Post-graduate Program in Forest Engineering, Curitiba, Paraná, Brazil - email: romano.timo@ gmail.com \\ ${ }^{3}$ Federal University of Paraná, Post-graduate Program in Forest Engineering, Curitiba, Paraná, Brazil - email: \\ dimas.agostinho.silva@gmail.com \\ ${ }^{4}$ Federal University of Paraná, Post-graduate Program in Forest Engineering, Curitiba, Paraná, Brazil - email: garzelufpr@gmail.com \\ ${ }^{5}$ State University of the West of Paraná, Post-graduate Program in Economics, Toledo, Paraná, Brazil - email: jandirbr@yahoo.ca
}

Submitted for publication: 16/09/2018 - Accepted for publication: 17/05/2019

\begin{abstract}
Resumo
A indústria de base florestal no paraná: aglomeração e geração de bioenergia. A proximidade territorial dos agentes econômicos e sociais atuantes numa determinada atividade pode proporcionar economias de aglomeração relacionadas, entre outros aspectos, à maior facilidade de acesso a conhecimento, capacitação de mão de obra especializada, matéria prima e também equipamentos. O problema da presente pesquisa consiste em compreender ${ }^{1}$ se existe concentração da indústria de base florestal de produtos madeireiros no estado do Paraná. O objetivo deste estudo foi identificar as regiões paranaenses que compõem o principal agrupamento da indústria de base florestal de produtos madeireiros e analisá-lo sob a ótica do potencial instalado para geração de energia elétrica a partir da biomassa florestal. A metodologia de pesquisa adotada foi a análise multivariada, por técnica de interdependência, através da análise de conglomerados. Essa técnica permite classificar as regiões paranaenses em grupos de modo que cada uma das regiões se assemelha às demais no agrupamento, mas diferencia-se dos agrupamentos restantes, com base em um conjunto de características - número de indústrias de base florestal, número de empregos na indústria de base florestal, Valor Adicionado Fiscal e área de floresta plantada. Os resultados obtidos sugerem a existência de dois agrupamentos. Conclui-se que no principal agrupamento todas as Microrregiões Geográficas exploram a biomassa florestal para fins de geração de energia elétrica, e respondem por $99,4 \%$ da capacidade total do Paraná em termos de geração de energia elétrica a partir de biomassa florestal, com potencial de expansão da potência instalada.

Palavras-chave: economia regional; floresta plantada; resíduo florestal.
\end{abstract}

\begin{abstract}
The territorial proximity of economic and social agents operating in an activity can result in agglomeration economies related, among other things, to more ease of access to knowledge, training of skilled labor, raw materials and equipment. The problem of the present research is to understand if there is a concentration of timber products from forest-based industries in the state of Paraná. The goal of this study was to identify the regions of Paraná that make up the main cluster of the forest-based industry and analyze it from the perspective of the installed capacity for electric power generation from forest biomass. The research methodology adopted was multivariate analysis, by interdependence technique, through cluster analysis. This technique makes it possible to classify the Paraná regions into groups so that each region resembles the others in the cluster but differs from the other clusters based on a set of characteristics - number of forest-based industries, number of jobs in the forest-based industry, Tax Value Added and planted forest area. The results suggest the existence of two clusters. In the main cluster, all the Geographic Microregions exploit forest biomass for electric power generation, and account for $99.4 \%$ of the total capacity of Paraná in terms of electricity generation from forest biomass, with potential for expanding the installed capacity.

Keywords: regional economy; planted forests; forest residues.
\end{abstract}

\section{INTRODUCTION}

Historically, biomass has been a relevant energy input for humanity, more intensively in developing countries. However, the value given to biomass as a modern energy input started in the 1970s, with the 1973 and 1979 oil crises. Although biomass is considered a viable alternative for energy purposes, since 1985 the price of oil has fallen again. This fact also reduced the interest in alternative energy sources. According to Santos et al. (2013), biomass only stood out again in the 1990s, stimulated by the development of more advanced transformation technologies, a new threat of depletion of fossil fuel reserves, the incorporation of environmental issues into

FLORESTA, Curitiba, PR, v. 50, n. 1, p. 1099 - 1106, jan/mar 2020.

Hersen, A. et.al.

ISSN eletrônico 1982-4688

DOI: $10.5380 /$ rf.v50 i1.61569 
discussions, and the Kyoto Protocol.

Biomass, intended for energy purposes, is a primary non-fossil energy source consisting of organic matter of animal or plant origin. Biomass contains energy stored in the form of chemical energy. Regarding their origin, biomass for energy purposes can be classified into the categories of forest biomass for energy, its products and byproducts or waste; energy biomass from agriculture, agroenergy crops and residues and by-products of agricultural, agroindustrial and livestock activities; and urban waste (Empresa de Pesquisa Energética-EPE, 2017).

The research problem is to understand if there is a concentration of forest-based industry for timber products in the state of Paraná, working with the initial hypothesis that there is a concentration of this type of industry in certain regions of the state of Paraná. Thus, this investigation aims to identify the regions of Paraná that make up the main cluster of the forest-based industries and discuss it from the perspective of the installed capacity for electric power generation from forest biomass. The specific objective is to identify, in the main cluster, indications of the existence of idle potential for electric power generation from forest biomass. The forest sector, in particular, and society in general will benefit from the information found in this study because it identified the regions in Paraná with the highest potential for electric power generation from forest biomass, a clean and renewable source of energy.

\section{MATERIALS AND METHOD}

Materials

The area covered by the study corresponds to the state of Paraná, in the South of Brazil. In 2015, a mapping carried out by the Paraná Forest Institute (IFPR) and the Brazilian Forest Service (SFB), with support from the Paraná Association of Forest-based Industries (APRE), and described in Eisfeld \& Nascimento (2015), pointed out that forest planted areas in Paraná totaled 1,066,479 hectares, which corresponds to approximately $5.4 \%$ of the state total area. According to the same study, of the total planted area, excluding shallow-cut areas, the pinus genus stands out for representing $65.8 \%$ of the total planted area. The eucalyptus genus covered $34.2 \%$ of the total planted area.

With such a broad forest planted area, the number of industries and direct jobs of the sector in the state was expressive. In 2016, the number of industries in the timber sector - including the Wood and Furniture Industry, Paper, Cardboard, Publishing and Printing - was 7,400, and the number of direct jobs generated in the industries of the sector for the same year was 105,290. These numbers represent $20.96 \%$ and $16.16 \%$ of the total of the Paraná industrial sector, respectively (Instituto Paranaense de Desenvolvimento Econômico e Social-IPARDES, 2017).

Considering the importance of the sector for the state of Paraná, an in-depth investigation of the location and identification of forest-based industry clusters in the state is relevant. In a complementary way, the perspective of the installed capacity for electric power generation has been added in order to highlight the concern with the proper disposal of the industrial waste and to stimulate the generation of clean and renewable energy, from forest biomass.

The objects grouped in the present research were the 39 Geographic Microregions (MRGs) of Paraná and the characteristics of the clusters, whose sources are secondary, are associated with the forest-based industry, detailed in Table 1.

Tabela 1. Variáveis de agrupamento das MRGs

Table 1. Variables of the MRGs clusters

\begin{tabular}{|c|c|c|c|}
\hline Code & Description & $\begin{array}{c}\text { Year of } \\
\text { Reference }\end{array}$ & Source \\
\hline I1 & Number of Wood and Furniture Industries & 2016 & Ipardes (2017) \\
\hline $\mathrm{I} 2$ & $\begin{array}{l}\text { Number of Paper, Cardboard, Publishing and Printing } \\
\text { Industries }\end{array}$ & 2016 & Ipardes (2017) \\
\hline E1 & Number of Jobs in the Wood and Furniture Industries & 2016 & Ipardes (2017) \\
\hline E2 & $\begin{array}{l}\text { Number of Jobs in the Paper, Cardboard, Publishing and } \\
\text { Printing Industries }\end{array}$ & 2016 & Ipardes (2017) \\
\hline $\mathrm{F} 1$ & Tax Added Value - Manufacture of Wood Products & 2016 & Ipardes (2017) \\
\hline $\mathrm{F} 2$ & $\begin{array}{l}\text { Tax Added Value - Manufacture of Pulp, Paper and Paper } \\
\text { Products }\end{array}$ & 2016 & Ipardes (2017) \\
\hline $\mathrm{H} 1$ & Total planted forest area (pinus and eucalipto) & 2011-2014 & $\begin{array}{c}\text { Eisfeld \& } \\
\text { Nascimento (2015) }\end{array}$ \\
\hline
\end{tabular}

Note: TAV - Tax Added Value; reference year for variables is 2016 except total planted forest area (2011-2014). 
The Paraná Institute of Economic and Social Development - Ipardes (2003) used the same variables described (Table 1), except for the variable "Total planted forest area". However, as the objective of the present research focuses exclusively on the forest industry, Weber's (1969) logic of Location Theory - detailed in Leme (1982); Clemente (1994); Andrade (2007); Costa \& Nijkamp (2009); Monasterio \& Cavalcante (2011); Dallabrida et al. (2011) - justifies the inclusion of the variable "Total planted forest area" in the set of cluster variables.

Method

Multivariate analysis was used to proceed with the proposed clustering. According to Hair et al. (2009), cluster analysis is an interdependent technique that classifies objects - respondents, products, entities, etc. - so that each object resembles the others in the cluster, based on a set of chosen characteristics. Thus, the objects within the cluster are homogeneous, but are heterogeneous between clusters.

The clustering technique consists of analyzing the geometric proximity between the studied objects. In this type of analysis, the distances between the studied objects within the multiplane space are calculated, constituted by axes of all the measurements made. Then the objects are clustered according to the proximity between them(JOHNSON e WICHERN, 1992).

Cluster analysis is applicable to the purpose of this research because, as stated by Linden (2009), clustering techniques can be applied to the most diverse and distinct areas. Moreover, grouping municipalities or regions by economic characteristics using multivariate cluster analysis is a widespread practice in the scientific community. Bemet al. (2015) used the clustering technique when conducting their research, which aimed to find possible clusters of cities in the Consinos Region of the state of Rio Grande do Sul, that developed creative activities and could perform them as a substitute for the footwear sector. Santos \& Ferreira (2017) sought to compare the socioeconomic reality of small cities in Minas Gerais, from the perspective of local human development, and used cluster analysis to characterize the cities as low, intermediate and high local human development.

To alleviate the possible occurrence of multicollinearity, the procedure adopted was to reduce the subjects (MRG) to close numbers in each cluster. No cases were eliminated to correct eventual existence of outliers, as they were considered extreme clusters. This was to follow the guidelines by Hair Jr. et al. (2009, p. 431), who stated that one must "[...] ensure that strong conceptual support precedes the application of the technique".

The use of variables with different scales or measures requires them to be standardized. The most widespread form of standardization, according to Hair Jr. et al. (2009), consists in transforming each variable into a standard score ( $\mathrm{Z}$ score). The $\mathrm{Z}$ score method standardizes each variable ( $\mathrm{x}$ ) to present mean zero and standard deviation 1 , according to the following equation:

$$
Z=\frac{(x-\bar{x})}{\sigma}
$$

In addition, cluster analysis requires the definition of the measure of similarity or dissimilarity (distance) to be used. Given that the data used in this research are metric, we used Euclidean Quadratic Distance as a distance measure, which, according to Favero et al. (2009), is the appropriate distance criterion for cluster formation in the Ward hierarchical method. Euclidean Quadratic Distance is given by:

$$
d_{i j}^{2}=\sum_{k=1}^{p}\left(x_{i k}-x_{j k}\right)^{2}
$$

In which $x_{\mathrm{ik}}$ is the value of variable $k$ referring to observation $i$, and $x_{\mathrm{jk}}$ represents variable $k$ for observation $j$.

After that, Hair Jr. et al. (2009) suggest the elaboration of the similarity matrix among all observations. After having prepared the matrix, the next step is to determine the algorithm that will make the clustering process, that is, specify the clustering method chosen.

For Hair Jr. et al. (2009), hierarchical solutions are preferable when all alternative solutions should be examined and when the sample size is moderate (300-400), which justifies their use in this research. The Ward method was chosen as the hierarchical solution. According to Favero et al. (2009), these are the steps followed by the Ward method: 1) calculate the means of the variables for each group; 2) calculate the square of the Euclidean distance between these means and the values of the variables for each individual; 3) add the distances for all individuals; and 4) minimize variance within clusters.

The final step of the technique is to determine the number of clusters and validation. The number of clusters was defined based on graphic visualization (dendrogram), as suggested by Favero et al. (2009). For validation, the author suggests, as an alternative, the use of different similarity measures. Therefore, we used the

FLORESTA, Curitiba, PR, v. 50, n. 1, p. 1099 - 1106, jan/mar 2020.

Hersen, A. et.al.

ISSN eletrônico 1982-4688

DOI: $10.5380 /$ rf.v50 i1.61569 
two step method, as described by Costa (2017). In addition, a thorough analysis of the characteristics (data) of each MRG was conducted.

\section{RESULTS}

After the methodological procedures regarding cluster analysis (section 2) were carried out, the following dendrogram was obtained (Fig. 1).

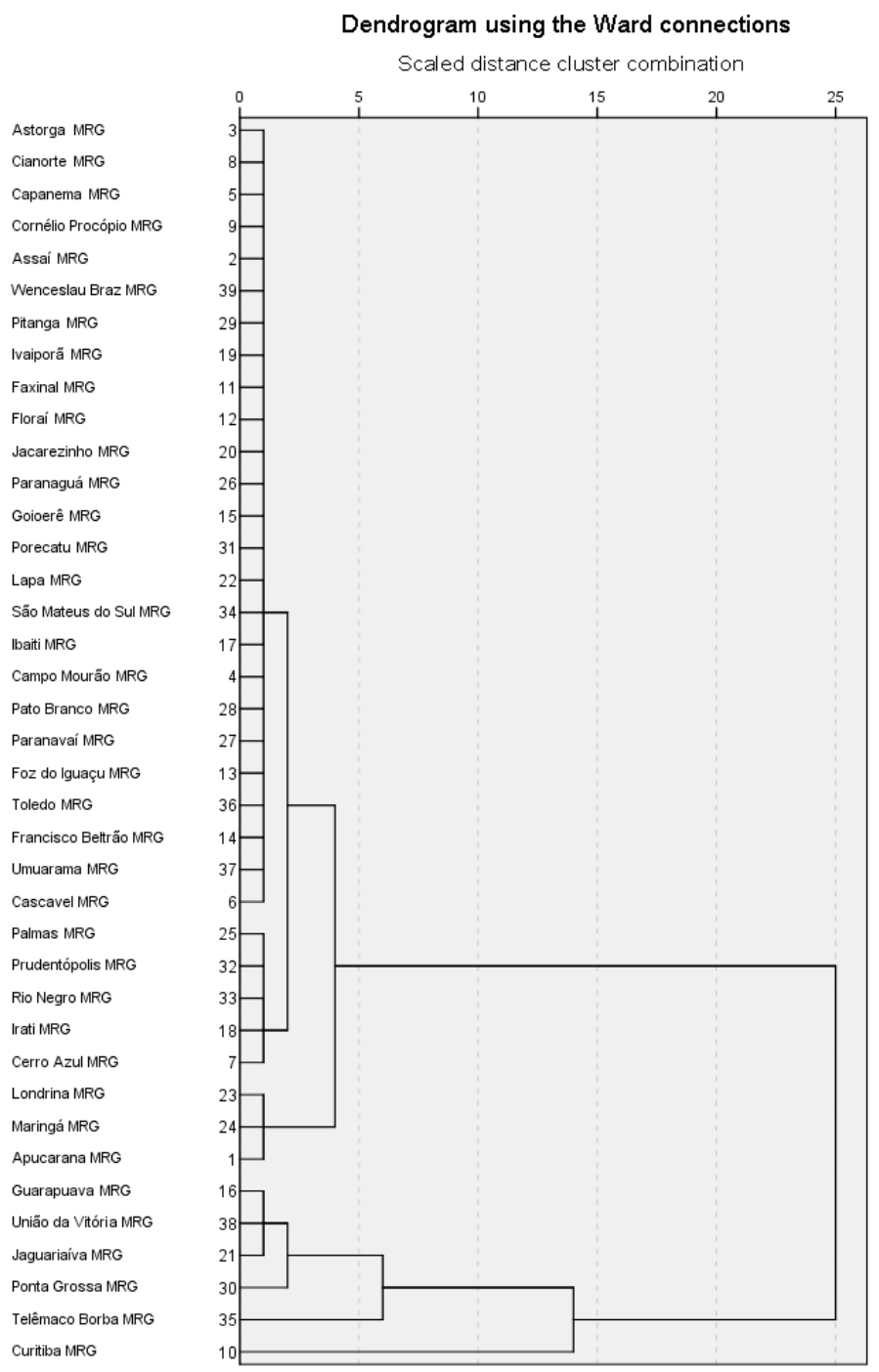

Figura 1. Dendrograma resultante da classificação de grupos

Figure 1. Dendrogram resulting from the cluster classification

The dendrogram shows the existence of two distinct clusters. The first cluster is made up of regions of notorious prominence in the forest sector in the state. The MRGs of Curitiba, Telêmaco Borba, Ponta Grossa, Jaguariaíva, União da Vitória and Guarapuava make up this group. The Curitiba MRG, which justifies its presence in the cluster by presenting outstanding numbers in all variables considered, holding the largest number of industries and jobs in the sector. The Telêmaco Borba MRG justifies its presence in the cluster by presenting the largest Tax Added Value in the sector and the largest area of planted forest among all regions of the State. The robustness of this region regarding TAV and planted forest area is mainly explained by the presence of the Klabin industry, Brazil's largest paper producer and exporter.

The Ponta Grossa MRG is in the main cluster for presenting the second largest TAV of the sector in the state, indicating that despite not having the highest numbers related to industries in the sector, it accommodates companies of relative size. The Jaguariaíva Microregion holds the second largest total area of planted forest and TAV (BRL 971.9 million), well above the State Microregions average (BRL 251.9 million). The Microregion of 
União da Vitória gained space in this cluster mainly because it has the fourth largest area of planted forest in the entire state, more than 78 thousand hectares. The Guarapuava MRG is in this select cluster because it has the third largest area of planted forest - more than 100 thousand hectares -, has close to 7 thousand jobs in the industry and holds the fifth largest TAV in the sector in the state.

In line with the results found, with regard to the regions that make up the main cluster, the works by Silva et al. (2011), Nunes et al. (2012), Schwab et al. (2012), Almeida et al. (2012), Faganello (2014), and Santos \& Silva (2017) have as study object industries of the forest sector in cities of the Regions of the main cluster, thus evidencing the importance of the forest-based industry for the referred regions of the cluster.

The second cluster, for the purpose of analysis, was divided into three subgroups. The first subgroup of the second cluster is formed by the Apucarana, Londrina and Maringá MRGs. The number of Wood and Furniture Industries, Paper, Cardboard, Editorial and Printing Industries was above the State average for the three Regions. What dissociated this subgroup from the first cluster was the fact that these regions have a small amount of planted forest area and TAV, well below the state average. The number of jobs created by the Apucarana MRG should be noted, one of the highest in the state.

The second subgroup is composed of the Cerro Azul, Irati, Palmas, Prudentópolis and Rio Negro MRGs. The striking and common feature among these regions is the fact that they have planted forest area close to or above the state average - which corresponds to approximately 27,000 ha. The regions of Rio Negro and Irati also stand out for presenting more expressive TAV.

Finally, the third subgroup, numerically larger than the others (25 MRGs). What the regions in this subgroup have in common is basically the availability of planted forest area, number of jobs in the sector, and TAV, all below the state average.

\section{DISCUSSION}

Once the main cluster was identified, it was characterized according to its capacity to generate electric power from forest biomass. The regions that make up the first cluster correspond to $99.4 \%$ of all electric power generated from forest biomass in the state of Paraná. The Telêmaco Borba MRG alone owns more than 198,000 hectares of planted forest and installed (granted) power for the generation of 443,250 kW of electricity. Despite having over 125,000 hectares of planted forest, The Jaguariaíva MRG only has 9,000kW of installed power for electric power generation. The Guarapuava MRG, with over 102,000 hectares of planted forest, has an installed capacity close to $19,000 \mathrm{~kW}$. The other MRGs of the cluster together amount to 201,253 ha of planted forest and $35,000 \mathrm{~kW}$ of installed power.

Disregarding factors such as gender, age, spacing of the plants, while the Telêmaco Borba MRG has installed power for electric power generation of around $2.24 \mathrm{~kW} / \mathrm{ha}$, the other MRGs have much lower usage $(0.23 \mathrm{~kW} / \mathrm{ha}$ in União da Vitória; $0.16 \mathrm{~kW} / \mathrm{ha}$ in Curitiba; $0.18 \mathrm{~kW} / \mathrm{ha}$ in Guarapuava; $0.10 \mathrm{~kW} / \mathrm{ha}$ in Ponta Grossa; $0.07 \mathrm{~kW} / \mathrm{ha}$ in Jaguariaíva).

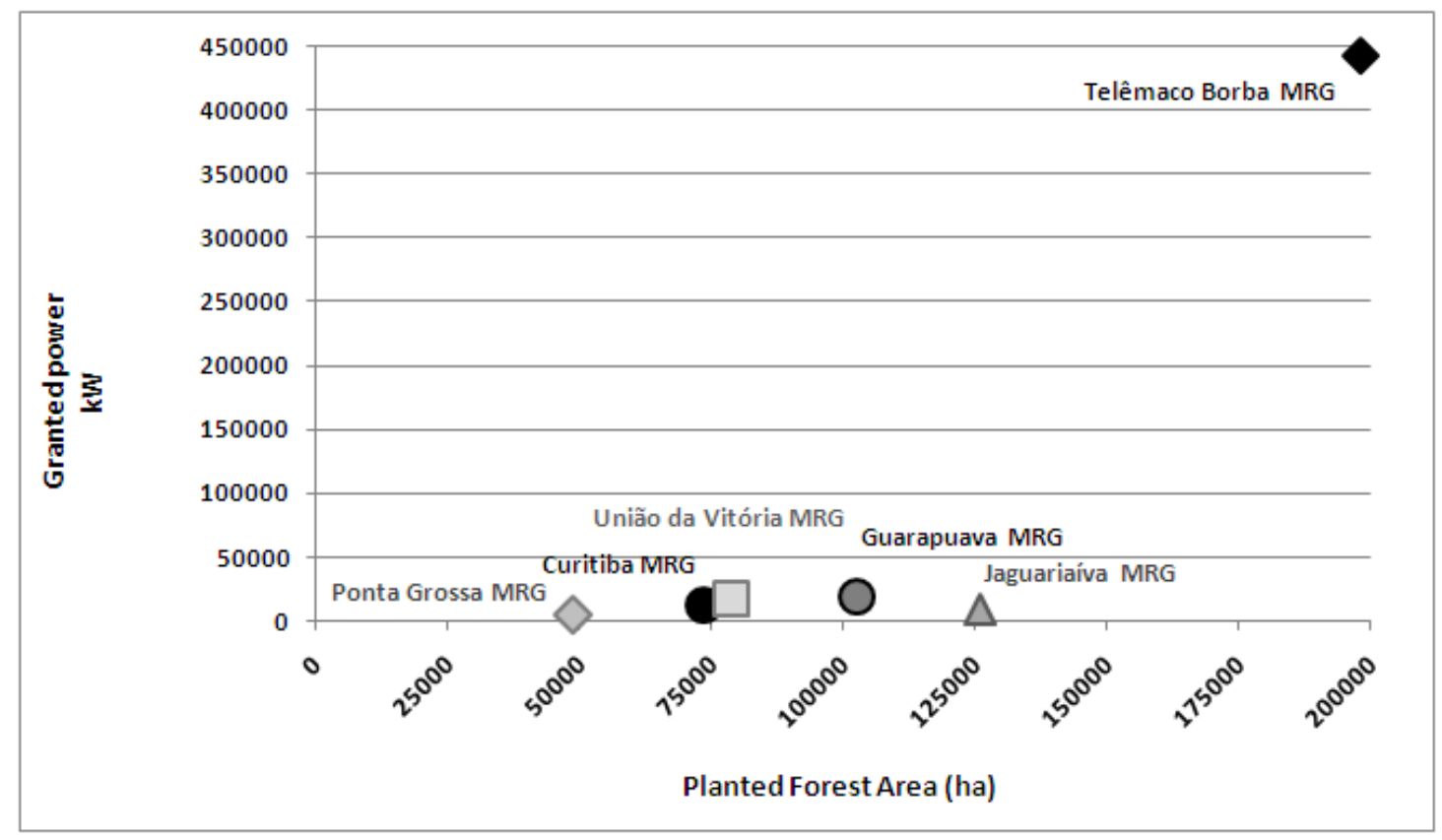

FLORESTA, Curitiba, PR, v. 50, n. 1, p. 1099 - 1106, jan/mar 2020.

Hersen, A. et.al.

ISSN eletrônico 1982-4688

DOI: $10.5380 /$ rf.v50 i1.61569 
Figura 2. Floresta plantada x Potência outorgada (Aneel) de termelétricas a base de biomassa florestal Figure 2. Planted Forest x Granted power (Aneel) of thermoelectric plants based on forest biomass

It is pertinent to analyze the number of industries and jobs in the sector from the perspective of the potential for electric power generation, given that the residues of the forest industry can be used to generate electric power. The number of industries contributes to the understanding of the number of waste-generating industrial units, and comparing the number of industries with the number of jobs helps to understand the size of the installed industrial units.

The Curitiba MRG presented the largest number of jobs $(73,616)$ and industrial units in the sector $(1,939)$, as shown in Figure 3. The Telêmaco Borba MRG had the second largest number of cluster jobs $(9,055)$, but the number of industries is one of the smallest in the cluster, suggesting the existence of a big industry (highlighting the Klabin S.A. industry). The Guarapuava MRG stood out with the second largest number of industries (315) and third highest number of jobs $(6,868)$.

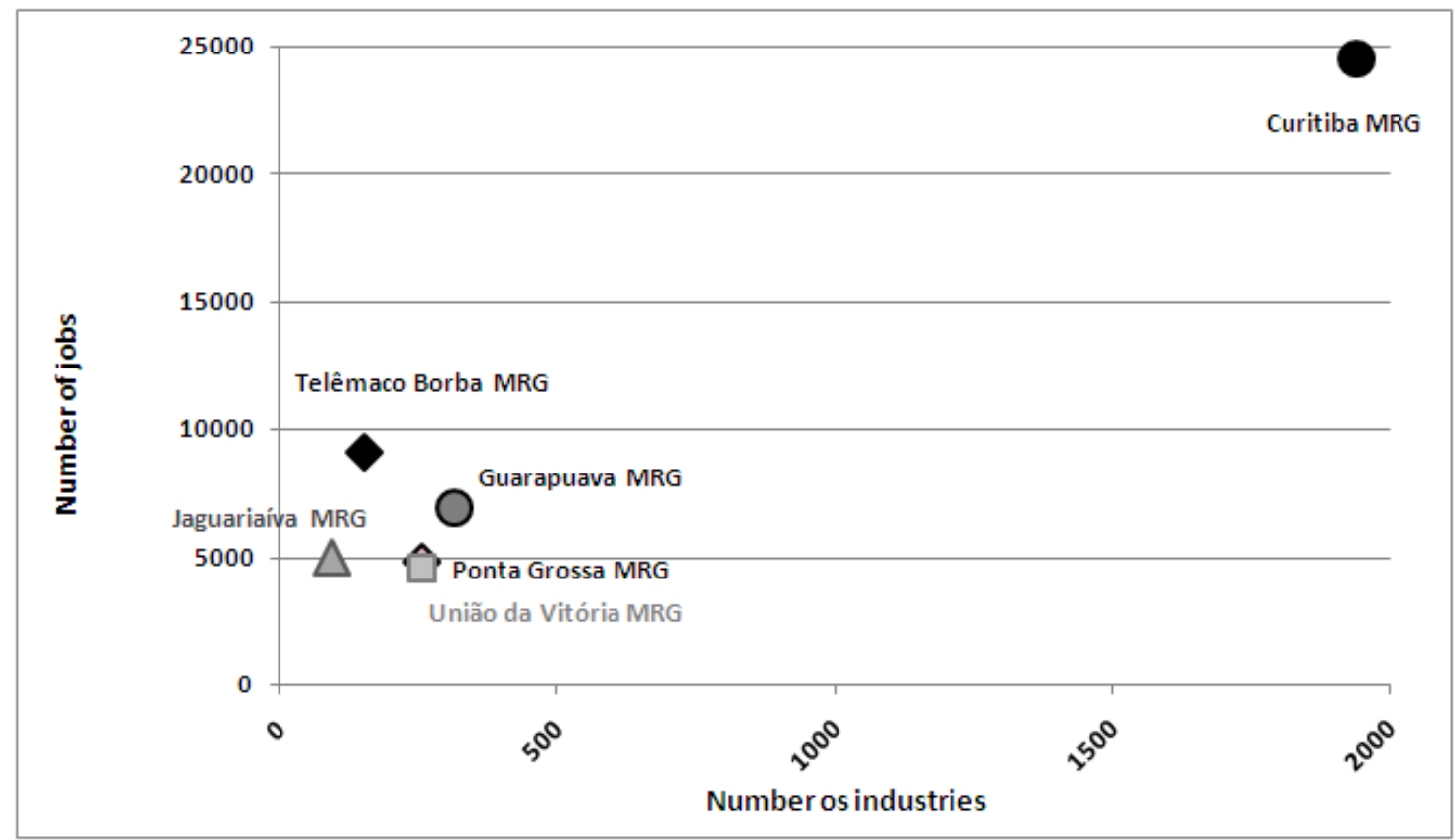

Figura 3. Número de Indústrias do setor x Número de empregos

Figure 3. Number of Industries in the Sector $x$ Number of jobs

Among the cluster's MRGs, the Curitiba MRG had the highest potential for industrial waste generation that could eventually be used for electric power generation, followed by the Guarapuava MRG.

\section{CONCLUSIONS}

- $\quad$ The results suggest the existence of two different clusters of the forest-based industry in Paraná. The first and main cluster is formed by the Geographic Microregions of Curitiba, Telêmaco Borba, Ponta Grossa, Jaguariaíva, União da Vitória and Guarapuava. The second cluster is formed by the other Microregions of the state.

- $\quad$ All Geographic Microregions of the first cluster exploit forest biomass for power generation purposes. However, the installed capacity for electric power generation in the Curitiba, Ponta Grossa, Jaguariaíva, União da Vitória and Guarapuava Geographic Microregions is significantly lower when compared to the Telêmaco Borba Geographic Microregion.

- $\quad$ Factors such as the installed sub-capacity for electric power generation from forest biomass, inadequate solid waste management by the industries of the sector and the absence of economic viability studies contribute to the result and merit further investigation in future research. 


\section{REFERENCES}

ANDRADE, W. S. P.; GOMES, M. F. M.; SANTOS, H. N.; DE LIMA, J. E. Localização economicamente ótima das novas agroindústrias de abate e processamento de aves e suínos no Brasil. Revista de Economia e Agronegócio - REA, Viçosa - MG, v. 5, n. 3, p. 379-400, 2007.

ALMEIDA, A. N.; SILVA, J. C. G. L.; ANGELO, H. Influência da Klabin no mercado de madeira em tora do estado do Paraná. Cerne, Lavras, v. 18, n. 1, p. 153-158, 2012.

BEM, J. S.; GIACOMINI, N. M. R.; WAISMANN, M. Utilização da técnica da análise de clusters ao emprego da indústria criativa entre 2000 e 2010: estudo da Região do Consinos, RS. Interações, Campo Grande, v. 16, n. 1, p. 27-41, 2015.

CLEMENTE, A. Economia regional e urbana. São Paulo: Ed. Atlas, 1994. 170p.

COSTA, G. G. O. Uso da técnica two step cluster para segmentação de funcionários de uma empresa no Rio de Janeiro segundo clima organizacional: um estudo de caso. Revista da Estatística UFOP, Ouro Preto, v. 6, p. 33 $56,2017$.

DALLABRIDA, V. R.; DESCHAMPS, M. V.; SCHIMALSK, M. B.; KNOREK, R. Aportes teóricometodológicos sobre a dimensão espacial do desenvolvimento: uma contribuição. DRd - Desenvolvimento Regional em debate, Canoinhas - SC, v. 1, n. 1, p. 190-209, 2011.

EISFELD, R. L. F.; NASCIMENTO, A. F. Mapeamento dos Plantios Florestais do Estado do Paraná: Pinus e Eucalyptus. Curitiba: Ed. Instituto de Florestas do Paraná, 2015, 72p.

EPE, Empresa de Pesquisa Energética. Balanço energético Nacional 2017: ano base 2016. Rio de Janeiro: Ed. EPE, 2017. 291p.

FAGANELLO, R. Marketing nas indústrias madeireiras de União da Vitória e Porto União. Luminária, União da Vitória - PR, v.16, n.02, p. 131-147, 2014.

FAVERO, L. P.; BELFIORE, P.; DA SILVA, F. L.; CHAN, B. L. Análise de dados: modelagem multivariada para tomada de decisões. Rio de Janeiro: Elsevier, 2009, 646p.

COSTA, J. S.; NIJKAMP, P. (Orgs). Compêndio de economia regional: teoria, temática e políticas. Portugal: Principia, 1 ed. 2009, 884p.

HAIR JR., J. F.; BLACK, W. C.; BABIN, B. J.; ANDERSON, R. E.; TATHAM, R. L. Análise multivariada de dados. Porto Alegre: Bookman, 6 ed. 2009, 688p.

IPARDES, Instituto Paranaense de Desenvolvimento Econômico e Social. Base de dados do estado. Disponível em: <http://www.ipardes.pr.gov.br/imp/index.php> Acesso em: 05/12/2017.

IPARDES, Instituto Paranaense de Desenvolvimento Econômico e Social. Arranjos produtivos locais e o novo padrão de especialização regional da indústria paranaense na década de 90. Curitiba: Ed. Ipardes, 2003, 95p.

JOHNSON, R; WICHERN, D. W. Applied multivariate statistical Analysis. London: Prentice-Hall, 1992, 641p.

LEME, R. A. S. Contribuições à teoria da localização industrial. SP: IPE/USP, 1982. 387p.

LINDEN, R. Técnicas de agrupamento. Revista de Sistemas de Informação da FSMA, Macaé, n. 4, p. 18-36, 2009.

MONASTERIO, L.; CAVALCANTE, L. R. Fundamentos do pensamento econômico regional. In CRUZ, B. O; FURTADO, B. A.; MONASTERIO, L.; RODRIGUES JÚNIOR, W. Economia regional e urbana: teorias e métodos com ênfase no Brasil. Brasília: Ed. IPEA, 2011, 406p.

NUNES, P. A.; MELO, C. O.; TEIXEIRA, D. A participação do setor madeireiro na economia das microrregiões geográficas do PR - 2009. Revista Brasileira de Agropecuária Sustentável-RBAS, Viçosa - MG, v.2,n.1, p. 820,2012

SANTOS, F.; COLODETTE, J.; QUEIROZ, J. H. Bioenergia \& biorrefinaria: cana de açúcar \& espécies florestais. Viçosa (MG): Ed. Os Editores, 2013, 551p.

SCHWAB, E. A.; MOMO, G.; MELO, E. Análise de mercado e o processo de vendas nas indústrias paranaenses: a situação de uma indústria de compensados em Curitiba-PR. Revista de Administração - IMED, Passo Fundo - RS, v.2, n.1, p. 35-50, 2012. 
SANTOS, P.; SILVA, M. R. A rede política da cadeia produtiva da madeira no Centro-Sul do Paraná: dinâmicas a partir da inserção internacional. Revista Formação, Presidente Prudente, v. 1, n. 25, p. 39-57, 2017.

SANTOS, V. J. C. F.; FERREIRA, F. P. M. Desenvolvimento humano local: uma análise multivariada para os pequenos municípios em Minas Gerais. Cadernos Gestão Pública e Cidadania, São Paulo, v. 22, n. 71, p37-56, 2017.

SILVA, H. P.; SILVA, C. L.; ANDREOLI, C. V. Atividade econômica de celulose e papel e desenvolvimento local: a história da Klabin e do município de Telêmaco Borba, PR. Interações, Campo Grande, v. 12, n. 2 , p. 137 148, 2011.

WEBER, A. Theory of the location of industries. Chicago: Chicago University, 1969, 256p. 